\title{
Incidence of filamentous fungii in normal oral mucosa of rural workers in the region of Frutal, MG
}

\section{Incidência de fungos filamentosos em mucosa oral normal de trabalhadores rurais da região de Frutal, MG}

\author{
DOI: $10.46919 / \operatorname{archv1n6-007}$
}

Recebimento dos originais: 01/09/2020

Aceitação para publicação: 30/10/2020

\section{Adriana Novaes Rodrigues}

Doutora em Ciências. Faculdade de Medicina da Universidade SãoPaulo, USP, Brasil.

Instituição: Universidade de São Paulo - USP

Endereço: Av. Dr. Arnaldo, 455 - Cerqueira César CEP: 01246903 São Paulo - SP - Brasil

E-mail: a.novaes@live.com

\section{Lourdes Conceição Martins}

Doutora em Ciências. Faculdade de Medicina da Universidade S.Paulo, USP, Brasil. Instituíção: Universidade Católica de Santos, 'Programa de Pós-Graduação em Saúde Coletiva. Endereço: Avenida Conselheiro Nébias - 300 -Vila Mathias. 11015002 - Santos, SP - Brasil

E-mail: lourdesc@usp.br

\section{João Ozório Rodrigues Neto}

Doutor em Ciências pela UNIRIO -/Saúde Coletiva

Instituição: Fundação Oswaldo Aranha - FOA - Brasil

Endereço: Campus Três Poços - Av. Paulo Erlei A. Abrantes, 1325 - Três Poços Prédio 1 - Volta Redonda - RJ - CEP: 27240-560

\section{Alfésio Luís Ferreira Braga}

Doutorado em Medicina. Universidade de São Paulo, USP, Brasil

Universidade Católica de Santos, Programa de Pós Graduação Em Saúde Coletiva.

Avenida Conselheiro Nébias, 300, Prédio Administrativo. Vila Mathias. 11015002 - Santos, SP - Brasil

E-mail: alfesio@gmail.com

\begin{abstract}
Working conditions give rise to health problems in a complex way, where specialist services are not always capable of finding a solution.Epidemiological studies evaluate these infections, both superficial and deep, and some of these studies perform an evaluation with regard to working and living conditions and the health of workers in a variety of areas. However, there are no bibliographical references in respect of filamentous fungal contamination of the oral cavity, related to rural labour activity.AIMS: To evaluate the incidence of fungal contamination in the normal oropharyngeal region of sugarcane, orange and pineapple plantation workers, in the municipality of Frutal, in the Brazilian state of Minas Gerais. METHODS: This constitutes a prospective, longitudinal study of the cohort type, of 60 temporary workers for each crop, making a comparison with the environment. The collection and analysis of material from the workers and from the environment followed the timing of each culture, designated as $\left(\mathrm{t}_{0}\right),\left(\mathrm{t}_{1}\right)$ and $\left(\mathrm{t}_{2}\right)$. RESULTS: Worker contamination occurred at the second interval of the study. Of the orange grove workers, $1.6 \%(\mathrm{~N}=1)$ were contaminated by $F$. subglutinans. In the sugarcane plantation, $8.3 \%(\mathrm{~N}=5)$ of workers were contaminated, $5 \%(\mathrm{~N}=3)$ by $A$. niger and 3.3\% $(\mathrm{N}=2)$ by $F$. moniliforme. The
\end{abstract}


two volunteers infected by $A$. niger were simultaneously infected by $C$. albicans. Of the sixty pineapple plantation workers analysed, $13.3 \%(\mathrm{~N}=8)$ were contaminated with $F$. subglutinans. CONCLUSIONS: This study showed that working with the pineapple crops was found to be a risk factor for fungal infection in the oral mucosa, when compared to the orange crop. Fungal contamination also occurred with the sugarcane crop, when compared to the reference group. Other factors, such as age, alcohol consumption, smoking, family income and ethnicity were not deemed to be statistically significant in the incidence of infection.

Keyword: Epidemiology, Filamentous fungi, Rural workers, Occupational health.

\section{RESUMO}

As condições de trabalho geram problemas de saúde de forma complexa, onde os serviços especializados nem sempre são capazes de encontrar uma solução.Os estudos epidemiológicos avaliam essas infecções, tanto superficiais quanto profundas, e alguns desses estudos fazem uma avaliação quanto às condições de trabalho e de vida e à saúde dos trabalhadores em diversas áreas. No entanto, não há referências bibliográficas a respeito da contaminação fúngica filamentosa da cavidade oral, relacionada à atividade laboral rural.OBJETIVOS: Avaliar a incidência de contaminação fúngica na região orofaríngea normal de trabalhadores de plantações de cana-de-açúcar, laranja e abacaxi, no município de Frutal, estado de Minas Gerais. MÉTODOS: Trata-se de um estudo prospectivo, longitudinal do tipo coorte, de 60 trabalhadores temporários para cada cultura, fazendo uma comparação com o meio ambiente. A coleta e análise do material dos trabalhadores e do ambiente seguiram o tempo de cada cultura, designados por (t0), (t1) e (t2). RESULTADOS: A contaminação dos trabalhadores ocorreu no segundo intervalo do estudo. Dos operários do laranjal, 1,6\% $(\mathrm{N}=1)$ estavam contaminadas por $\mathrm{F}$. subglutinans. No canavial, 8,3\% $(\mathrm{N}=5)$ dos trabalhadores estavam contaminados, $5 \%(\mathrm{~N}=3)$ por A. niger e $3,3 \%(\mathrm{~N}=2)$ por $\mathrm{F}$. moniliforme. Os dois voluntários infectados por A. niger foram infectados simultaneamente por C. albicans. Dos sessenta trabalhadores da plantação de abacaxi analisados, 13,3\% ( $\mathrm{N}=8)$ estavam contaminados com $\mathrm{F}$. subglutinans. CONCLUSÕES: Este estudo mostrou que o trabalho com a cultura do abacaxi é considerado um fator de risco para infecção fúngica na mucosa bucal, quando comparado à cultura da laranja. A contaminação fúngica também ocorreu com a cultura da cana-de-açúcar, quando comparada ao grupo de referência. Outros fatores, como idade, consumo de álcool, tabagismo, renda familiar e etnia, não foram considerados estatisticamente significativos na incidência de infecção.

Palavra-Chave: Epidemiologia, Fungos filamentosos, Trabalhadores rurais, Saúde Ocupacional.

\section{INTRODUCTION}

Filamentous fungi are part of the microbiomes of living creatures ${ }^{1}$ and, despite being considered a minor component, fungi have been recognised as playing an important role in these communities and have been the subject of several studies ${ }^{2}$. The oral cavity is an area prone to microbial growth ${ }^{3}$ and, even when healthy, the oral region could be home to over 75 kinds of different fungi ${ }^{4}$.

Knowledge of the relationship between occupations and getting ill is an integral part of the culture of humanity, and oral health is included in this process of human beings falling ill $^{5}$.

Working conditions give rise to health problems in a complex way, where specialist services are not always capable of finding a solution ${ }^{6}$ and rapid, severe changes in the environmental equilibrium directly or indirectly determine many of today's illnesses ${ }^{7}$. 
Epidemiological studies evaluate these infections, both superficial and deep, and some of these studies perform an evaluation with regard to working and living conditions and the health of workers in a variety of areas. However, there are no bibliographical references in respect of filamentous fungal contamination of the oral cavity, related to rural labour activity.

\section{AIM}

To evaluate the incidence of filamentous fungi in the normal oral mucosa of rural workers involved with sugarcane, pineapple and orange crops in the region of Frutal, in the Brazilian state of Minas Gerais.

\section{METHOD}

This is a prospective, longitudinal study of the cohort type to evaluate the incidence of fungal contamination in the normal oral mucosa in three distinct agricultural populations in the municipality of Frutal, in the Brazilian state of Minas Gerais, situated at 2001'29"S and 48 $56^{\prime} 25^{\prime \prime} \mathrm{W}$. The crops being analysed are sugarcane, pineapples and oranges. As the sampling calculation was based on the daily, clinical observation that the fungal infection in the oral mucosa of pineapple workers was three times more common than among orange workers, i.e. a difference of thirty to ten percent (30\% versus $10 \%)$, a two-tailed test with a power of $80 \%$ and level of significance of 5\% was adopted, estimating a total of 60 workers in each group analysed. The study participants were analysed demographically in terms of sex, race and socioeconomic status.

Culture samples were collected at three time intervals, both for the workers and for the environment, as shown in Figure 1. 
Figure 1 - Study flow on timeline

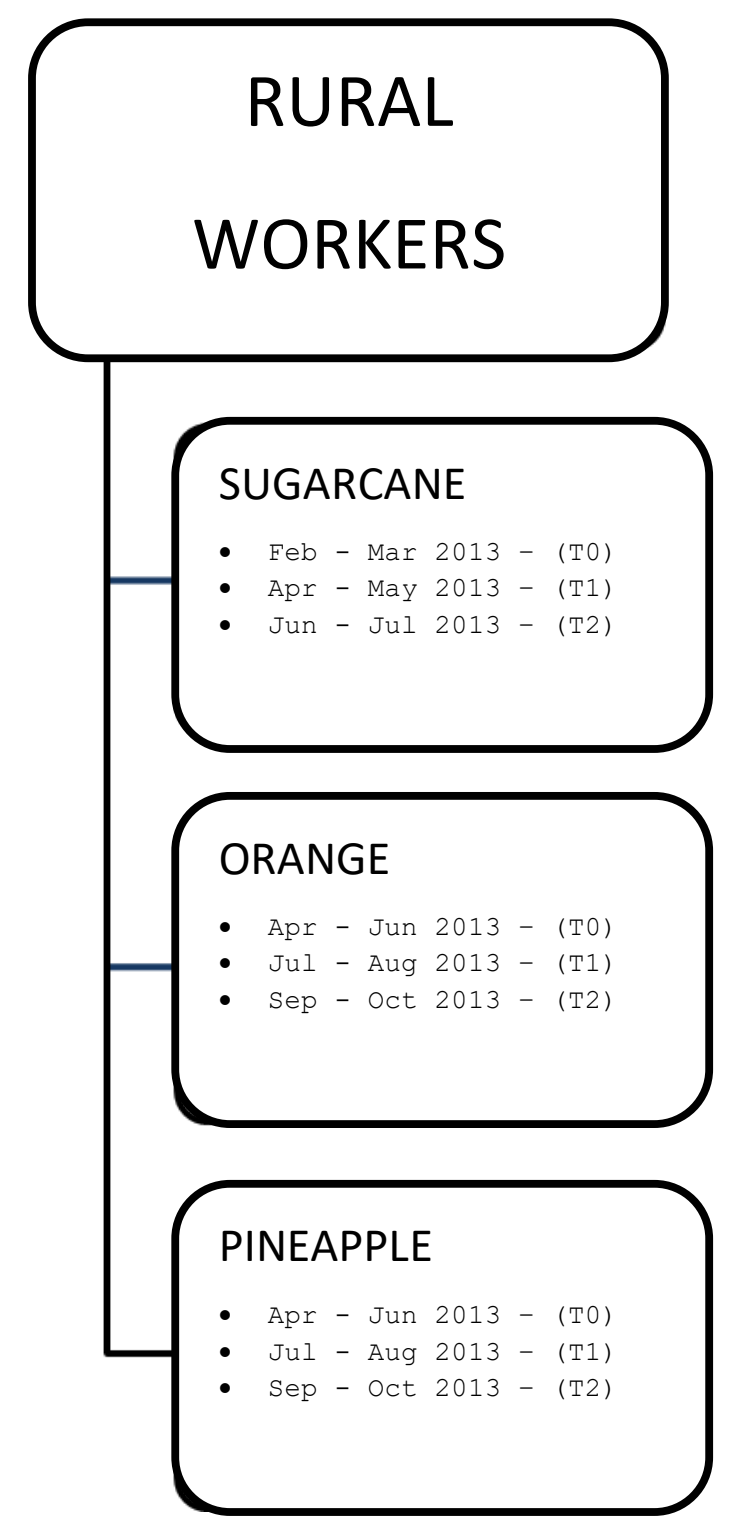

The clinical examination for all workers was carried out by a single examiner, the material having been collected from the oral mucosa in the region of the gingival labial sulcus, close to the region of the upper and lower labial frena; material from the mucous membrane of left and right cheeks ${ }^{8}$, using one swab per region ${ }^{9}$, arranged on a Petri dish, in accordance with the anatomy of the mouth, during the sugarcane, pineapple and orange crop cycles. The inclusion criteria were as follows: aged between 21 and 40 , not having any oral mucosa disease at the time of selection, not using any hormonal or non-hormonal anti-inflammatory medication, antibiotics, antifungal agents, mouthwashes or immunosuppressants ${ }^{10}$.

As far as the environment is concerned, the air was examined through the exposure of ten Petri dishes, arranged 500 meters apart from each other, at a height of 1.2 meters from the ground, at rest, for a period of 30 minutes and in a horizontal position ${ }^{11}$; as for the plants, these were picked and seeded directly on to the surface of the medium, untreated, though slightly softened ${ }^{12}$, at three time intervals: $\left(t_{0}\right)$, 
$\left(t_{1}\right)$ and $\left(t_{2}\right)$. The culture medium for fungi was obtained from the NEOGEN laboratory, 7306A, batch 104, 985B. The identification of the filamentous fungi was based on Steele and Stowers, $(1991)^{13}$.

As for smoking and alcohol consumption, the decision was taken to consider only an exploratory, dichotomous exposure variable for these two items, without taking into consideration the amount of tobacco and/or alcohol consumed ${ }^{14}$.

This study was approved by the Research Ethics Committee of the Faculty of Medicine at the University of São Paulo, in accordance with Law 196 of October 1996, under approval no. 200/11

For the statistical analysis, descriptive analyses were performed of all the variables used in the study. The continuous variables were displayed in relation to their central tendency and dispersion values, and the categorical variables as absolute and relative values.

The incidence of filamentous fungi in the oral mucosa was calculated over the different periods of time defined in the study and for the entire period of work in the three worker groups.

The Kruskal-Wallis test was used to test the differences in the continuous variables between the three groups of workers. To test the association between the categorical variables, the Pearson chi-square and Fisher's exact tests were used.

In order to investigate risk or protection factors for fungal infection in the oral mucosa in the three groups of rural workers, we used univariate and multiple logistical regression models.

A statistical significance of $5 \%$ was employed for all the tests.

The analyses were performed using the Statistical Package for Social Sciences (SPSS), version 15.

\section{RESULTS}

The sociodemographic characteristics of the study participants are analysed in Table 1.

Table 1 - Descriptive analysis of the demographic and income characteristics of the rural workers. Kruskal-Wallis test on sugarcane and pineapple crops with $\mathrm{p}>0.05 ; 2$ - Kruskal-Wallis test on orange and pineapple crops with p>0.05.

\begin{tabular}{cccc}
\hline Variables & \multicolumn{3}{c}{ Rural Worker Group } \\
\cline { 2 - 4 } & Sugarcane & Orange & Pineapple \\
\hline Age (years) - mean \pm SD & $27.73 \pm 3.75$ & $27.50 \pm 3.14$ & $30.83 \pm 5.60^{1,2}$ \\
Male $-\mathrm{N}(\%)$ & $58(96.7)$ & $44(73.3)$ & $52(86.7)$ \\
Race $-\mathrm{N}(\%)$ & & & \\
Caucasian & $17(28.3)$ & $25(41.7)$ & $32(53.3)$ \\
Afro-descendants & $43(71.7)$ & $35(58.3)$ & $18(30.0)$ \\
Oriental & 0 & 0 & $10(16.7)$ \\
Monthly Income (USD)- mean & 850 & 800 & 900 \\
Smokers - N (\%) & $7(11.7)$ & $8(13.3)$ & $22(36.7)$ \\
Drinkers - N (\%) & $12(20.0)$ & $15(25.0)$ & $10(16.7)$ \\
\hline
\end{tabular}


There is little difference in terms of age, the sugarcane and orange workers being, on average, younger than the pineapple workers. As for gender in the three groups, over three quarters of the workers were male and this male predominance was more evident in the sugarcane workers group. As for race, there was a predominance of workers of African origin in the sugarcane and orange crops when compated to pineapple workers, who were predominantly Caucasian. Workers of oriental origin were only found in the pineapple plantation.

As for income, the pineapple workers earn higher salaries than those in the other two groups.

The percentage of smokers was highest among pineapple workers and lowest among sugarcane workers. The same was true of the alcohol variable. There was no difference with regard to alcohol intake (Kruskal-Wallis $\mathrm{p}=0.06$ ) and smoking (Kruskal-Wallis $\mathrm{p}=0.54$ ) among the three groups.

As for environmental contamination, both plants and the air, we found a higher rate of contaminated Petri dishes in the pineapple planation, followed by the sugarcane plantation. This contamination is evaluated in figure 2 .

Figure 2 - Percentage of contaminated Petri dishes at the time intervals defined in this study (10 dishes in each field by time period).

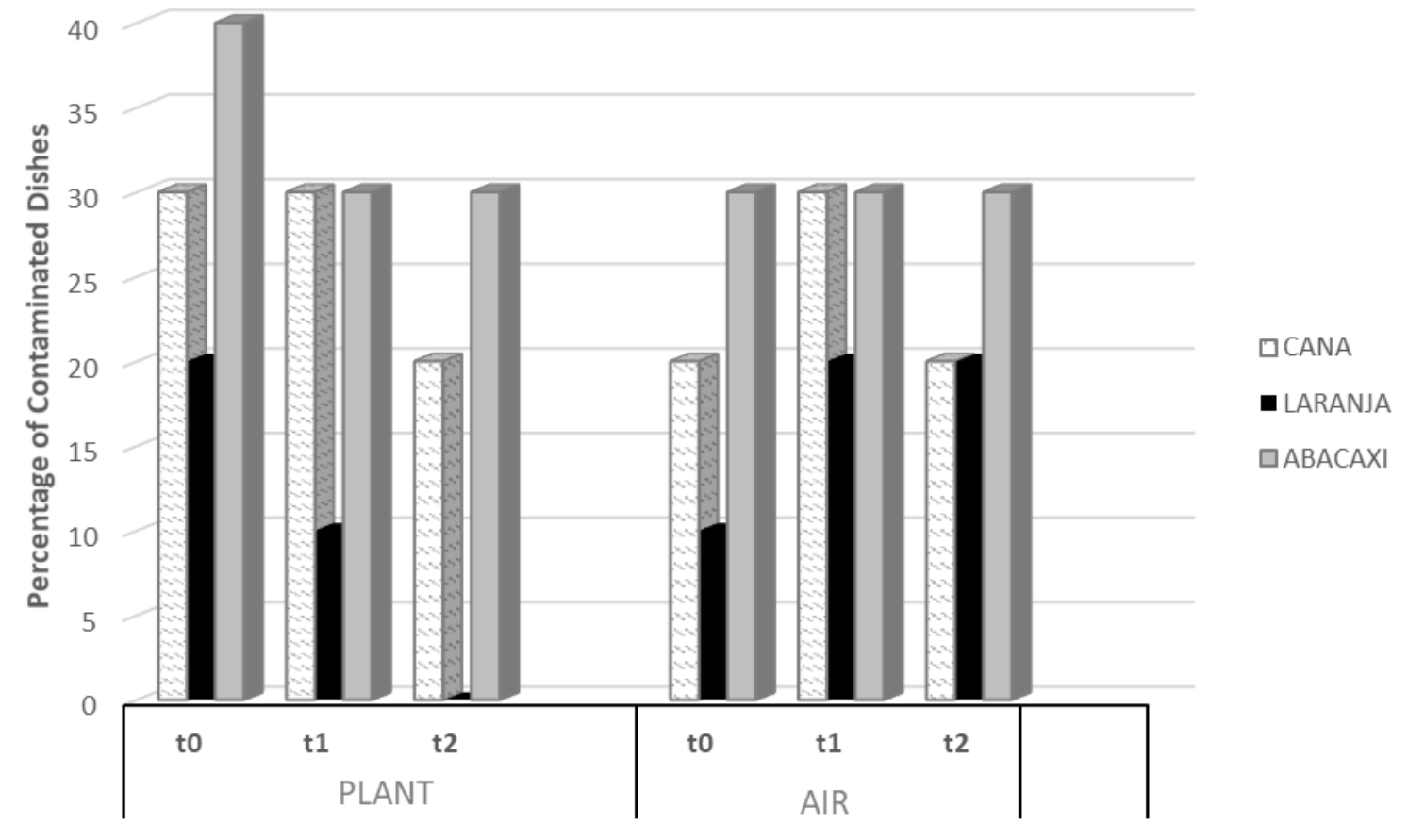


With regard to the contaminating fungi found in the plants in the environment, as described in figure 3, we observed a predominance of $F$. moniliforme in the sugarcane crop and $F$. subglutinans in the orange and pineapple crops in the periods covered by this study. Puccinia melanocephala was only present in the sugarcane fields. Here, at time $\left(\mathrm{t}_{0}\right)$, three dishes were found to be contaminated by two different fungi, while at $\left(\mathrm{t}_{1}\right)$, one dish was contaminated and at $\left(\mathrm{t}_{2}\right)$, two dishes. No contaminating fungi were found in the orange groves at time $\left(\mathrm{t}_{2}\right)$. As for contamination through the air, in the sugarcane fields, one dish had the three types of listed fungi at time intervals $\left(\mathrm{t}_{1}\right)$ and $\left(\mathrm{t}_{2}\right)$. As for pineapple contamination, at $\left(\mathrm{t}_{0}\right)$ and $\left(\mathrm{t}_{2}\right)$, one dish was found to have two types of fungi.

Figure 3 - Number of colonies found, as contaminants at the three time intervals analysed, for the crops and the environment.

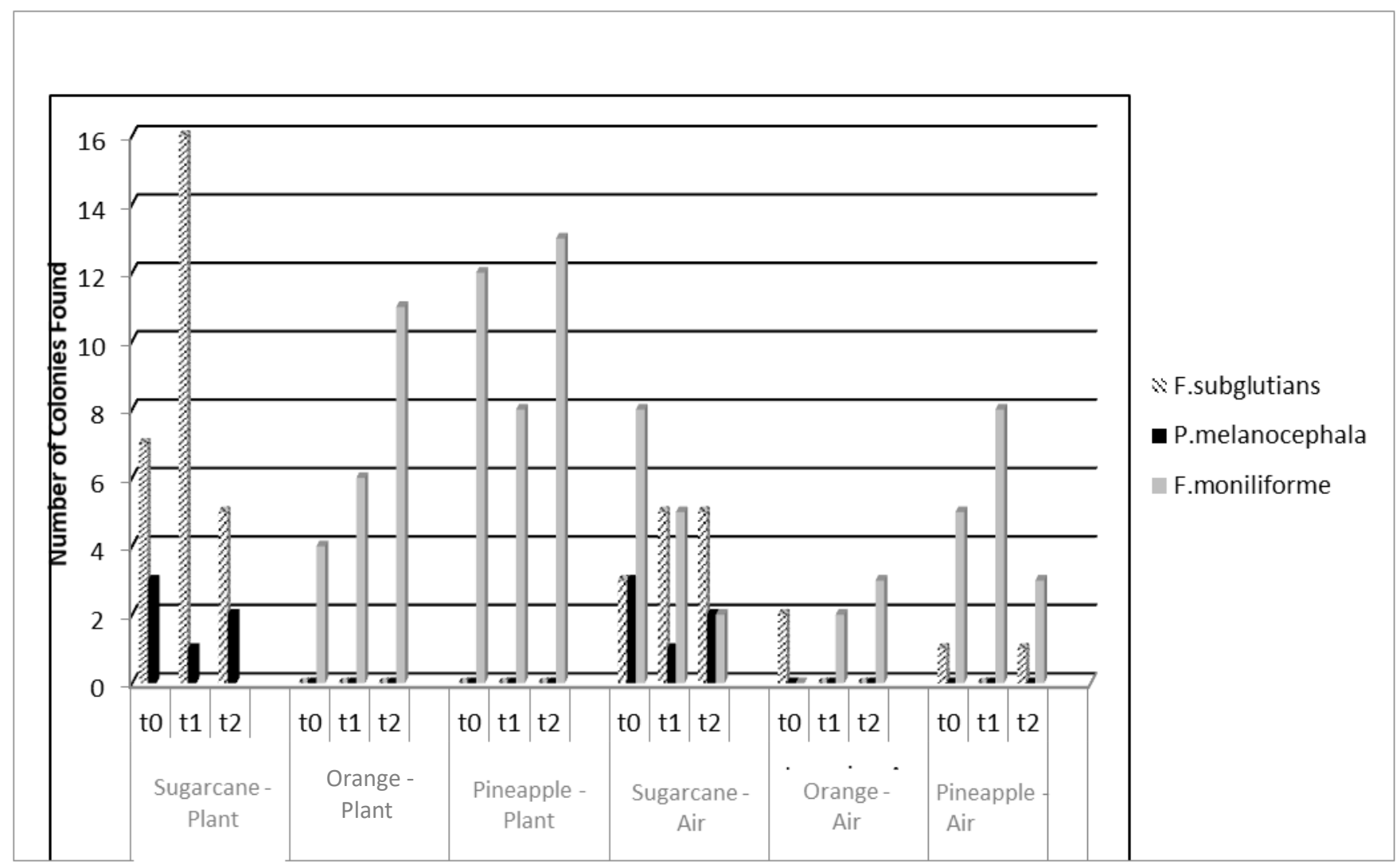

Figure 4 shows fungal contamination in workers for the three crops analysed. Worker contamination for the three crops occurred in the second phase of the study, at time $\left(\mathrm{t}_{1}\right)$. 
Figure 4 - Number of workers with fungal contamination at the study's respective time intervals

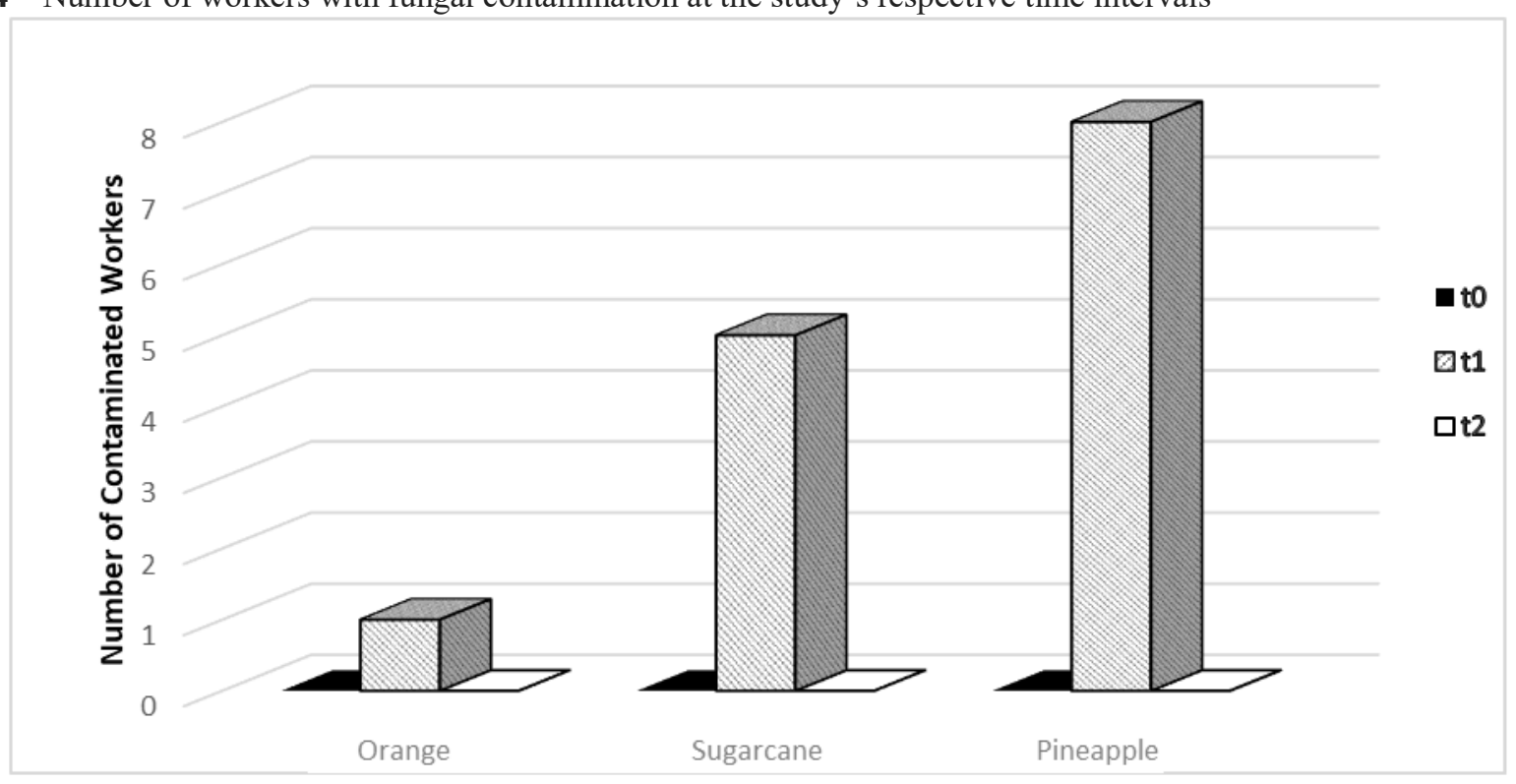

Of the orange grove workers, $1.6 \%(\mathrm{~N}=1)$ were contaminated by $F$. subglutinans. As for the sugarcane plantation, $8.3 \%(\mathrm{~N}=5)$ of workers were contaminated, $5 \%(\mathrm{~N}=3)$ by $A$. niger and 3.3\% $(\mathrm{N}=2)$ by $F$. moniliforme. The two volunteers infected by A. niger were simultaneously infected by C. albicans. Of the sixty workers analysed on the pineapple plantations, $13.3 \%(\mathrm{~N}=8)$ were contaminated by $F$. subglutinans.

The risk of contamination was assessed in workers of the three crops defined in this study. Table 2 displays the results of univariate logistical regression to investigate risk factors for fungal infection of the oral mucosa. Working on the pineapple plantation is shown to be one of these risk factors, taking the sugarcane and orange crops into consideration. None of the other demographic characteristics was considered to be a statistically significant risk or protection factor.

Table 2 - Odds ratio confidence interval of $95 \%$ for variables included in the individual models for investigating risk factors for fungal infection in the oral mucosa.

\begin{tabular}{ccc}
\hline Variables & OR & 95\% CI \\
\hline Age Groups & 1 & - \\
$20-30$ years & 0.65 & $0.17-2.44$ \\
$>30$ years & & - \\
Smokers & 1 & $0.46-7.0$ \\
No & 1.8 & - \\
Yes & & $0.37-5.58$ \\
Drinkers & 1 & \\
No & 1.45 &
\end{tabular}

Monthly Income 


\begin{tabular}{ccc}
$\geq 851$ (USD) & 1 & - \\
$\leq 850$ (USD) & 2.2 & $0.27-17.50$ \\
Group of Workers & & - \\
Orange & 1 & $0.61-47.36$ \\
Sugarcane & 5.36 & $1.10-75.02$ \\
Pineapple & 9.08 & \\
\hline
\end{tabular}

\section{DISCUSSION}

This study showed that working on the pineapple crop is a risk factor for fungal infection in the oral mucosa, when compared with orange crop activities. Moreover, there was fungal contamination in the sugarcane crop in the study's reference group. Other factors, such as age, rate of alcohol consumption, smoking, family income and ethnicity were not found to be statistically significant factors in the incidence of filamentous fungal infection.

This is the first research study in the world to study fungal contamination by filamentous fungi in the oral mucosa of rural workers. Taking into account the working difficulties and scant health conditions, ranging from shift-work to employer relations, this study presents important new information which, when added to other studies which have investigated other health conditions in the population, seeks to provide a more complete evaluation of the situation of rural workers.

Fungal contamination in workers of the three crops occurred in the second phase of the study $\left(\mathrm{t}_{1}\right)$, the most common agent being the fungus of the Fusarium genus.

In the work activities covered by this study, direct contamination by filamentous fungi in the oral mucosa may occur on account of two factors: the first relates to the ergonomic posture of the workers and the second to work-related habits.

In the pineapple plantation, occupational risks exist in all stages of the production process and it is rare to find the use of any form of Personal Protective Equipment (PPE). Being a virtually stalkless, herbaceous plant, its planting takes place in a leaning or crouching position ${ }^{15}$, where the oral region is much closer to the plant and the soil, making it easier to inhale dust and fungi.

The sugarcane workers also exhibited more significant levels of contamination than the orange crop control group. When working with sugarcane, proximity to the airways is lower than when working with pineapples, as many workers use a rolled-up cloth on their faces, blocking the nose and mouth, besides the fact that the sugarcane plants attain a great height from the stem (between 3 and 6 meters high $)^{16}$, thus the cutter is always working in an inclined posture.

As far as the orange workers are concerned, only one was contaminated. In field evaluations, it can be seen that the seedlings are already 1.5 meters tall and $3 \mathrm{~cm}$ in diameter, and adult trees reach a height close to 8 meters ${ }^{17}$. Orange workers normally use ladders or shears adapted for manual use and 
their ergonomic position is more erect due to the height of the citrus tree. These practices, together with the use of nose and mouth blockers for protection ${ }^{18}$, minimise contact of the oral region with soil and plants.

With regard to agricultural practices, rural workers have a habit of putting plant twigs or reeds in their mouth while they work. Small lesions caused by this habit act as an access route for various pathologies ${ }^{19}$. These situations are observed in the three crops analysed, mainly sugarcane and pineapples.

The scientific study which most closely approximates the present study was conducted by Martins-Diniz et al. $(2005)^{20}$, analysing filamentous fungal infection in the oropharynx, in people working in intensive care units and surgical centres. Coincidentally, the incidence of fungal contamination in the oropharynx was similar to that found in the present study. Moreover, the genus Cladosporium was the fungus most frequently obtained by these authors. Different working environments present peculiar characteristics which may nurture fungal infestation in the workers who frequent them. Identifying these factors and combatting them should be part of routine workplace inspections.

Micro-organisms in the oral cavity are part of a complex community and are critical components of the health-disease combination. Although the fungal component is an element of the oral microbiota, it has still not been properly identified ${ }^{21}$.

Sociodemographic characteristics, in respect of sex, age and colour, are linked to the beginning of the colonization of Brazil, with the use of slave labour, rural activities being mainly carried out by males, and this status quo remained for many decades, having been described by various authors over the last 50 years $^{22}$. The findings of this study confirm that these characteristics still persist, with a predominance of dark-skinned males approximately 30 years old, for the three crops analysed.

As far as income is concerned, in a case-control study conducted by Prasad et al. (2014) ${ }^{23}$ involving 150 immunocompetent rural workers in India, it was found that a monthly income lower than 5,000 Indian rupees (US\$ 77.18) was seen to be a risk factor for filamentous otitis, when compared with a monthly income greater than or equal to 20,000 Indian rupees (US\$ 308.70). In the present study, workers' incomes were far higher than those of the Indian workers evaluated in the abovementioned study. Nevertheless, despite the absence of statistical significance, being in a lower income group was seen to be a potential risk factor for fungal infection in the oropharynx.

Clinical-epidemiological evidence has indicated that factors or habits associated with smoking and alcohol consumption may promote the appearance of fungal contamination through deleterious action on the immune system ${ }^{24}$. The present study found no statistical relationship for these habits. 
Fusarium, the genus most commonly found in this study, can be found in the soil, in plants and in the air, surviving for months in these environments ${ }^{25}$, the same species as those found in the studies by Vieira et al. (1989) ${ }^{26}$.

Their taxonomic classification shows very similar species with an important role in the stability of the microbial community ${ }^{27}$, as can be observed between $F$. subglutinans and $F$. moniliforme. Genomic methods for identifying fungus species and communities are still very limited in comparison with those available for bacteria ${ }^{28}$. For this study, it was decided to retain this division since, although some authors consider them variants, they have the same potential for pathogenicity ${ }^{29}$.

In human beings, species of Fusarium may cause superficial, locally invasive and disseminated infections, the more serious cases being related to immune-incompetent individuals. The clinical importance of this genus is also related to the production of mycotoxins, mainly the fuminosins, a secondary metabolic product of the F. moniliforme ${ }^{28}$. It is, however, important to stress that the Fusarium genus may be present in the region of the oropharynx of healthy individuals, which was demonstrated by the study of Ghannoum et al. $(2010)^{21}$, where they found almost $30 \%(\mathrm{~N}=20)$ of their analytes to be contaminated by this genus.

As for the occupational hazards from fungi, it can be seen that the agriculture sector has the highest risk of skin disease, around $20 \%$ being caused by fungi ${ }^{30}$.

The vast majority of mycoses are opportunistic and immunodeficiency-related which, for the most part, start out at the level of the respiratory tract or the skin or mucosa ${ }^{31}$. As far as muco-cutaneous contamination is concerned, fungal infections are frequently associated with people whose professional activities involve the handling of earth and livestock ${ }^{32}$. It occurs via small lesions caused by material that is aggressive to the skin and mucosae, such as splinters and thorns, putting agricultural workers in higher risk of contamination through these lesions ${ }^{32}$.

The insalubrious environment arising from solar radiation, the presence of particles in the air and infectious, parasitic agents, as well as the lack of hygiene and the fact that rural workers take their meals in the location of the crops, leading to the disposal of leftover food directly on to the soil, create a situation which promotes fungal growth in the environment ${ }^{30}$.

The high rate of fungi in plantations may possibly be explained by examining the situation of farmers in the southeast and midwest regions of Brazil. Pest control on the plantations is, for the most part, the responsibility of the landowner or tenant. Fungal control in the three crops analysed is an expensive procedure, amounting for as much as $30 \%$ of production costs. The high cost leads to flaws in preventive action since farmers prefer to have lower productivity, reducing fungicidal irrigation in the fields, but which significantly increases the risks to workers' health ${ }^{33}$. 
Turning specifically to the situation of the orange crop, it is important to highlight that the resumption by Brazilian citrus farmers of an old important practice for controlling pests, namely pruning ${ }^{34}$, significantly reduces the presence of fungi in plants, principally those which grow under the canopy $^{35}$, which could explain the low rate of contamination in these crops. This compounds the rate of contamination found in orange grove workers.

The present study demonstrates that the fungi present in the workers were the same as those found in their place of work. However, unlike the genus Fusarium, most commonly found in the plantations analysed, Aspergillus niger is not a fungus that is common to them. Despite being widely found in terrestrial biomes, there are no reports of illnesses caused by Aspergillus niger in grasses. In the present study, three sugarcane workers revealed contamination by this fungus, two of them simultaneously infected by $C$. albicans. The Candida and Aspergillus species represent around $70 \%$ of species causing fungal infections in humans ${ }^{36}$. The pathogenic power of Candida $s p$ is dependent not only on host factors but also pathogenicity factors in the fungus. Among the Candida species that can cause candidiasis, Candida albicans predominates, including in the oropharynx ${ }^{37}$. The presence of $C$. albicans does not necessarily mean that there is host immunosuppression, since yeasts were isolated from the oral region of normal volunteers, using a methodology similar to that employed in this study ${ }^{38}$. As for Aspergillus niger, this is considered to be an emerging agent, capable of effective propagation in different environments and is one of the agents responsible for aspergillosis in humans, being, in the main, opportunistic. Sugarcane is rich in cellulose, hemicellulose and lignin, and these substances were shown to be a culture medium for fungi over and above the standard media, and eight species of fungi, including Aspergillus niger, Candida albicans and Fusarium sp, establishing an environment capable of providing nutrition, as well as preventing the growth of any bacterial contaminant and increasing the production of spores ${ }^{39}$. So it can be seen that the plantation environment, with the presence of sugarcane straw and bagasse, is a medium which is ripe for fungal growth in the fields, even for A. Niger, causing an increased risk of oropharynx infection in the workers. In other words, sugarcane working activities take place in a natural culture medium for fungi.

The results of this study show that the incidence of human contamination by filamentous fungi in the pineapple and sugarcane crops was higher than that found in those working in the orange groves.

Agricultural work, strictly speaking, involves activities composed of rural workers responsible for performing jobs ranging from planting to crop development, culminating in the harvest ${ }^{40}$. Nowadays, when we talk of working in the countryside, we would also include operators of various types of machinery, responsible for activities related to tillage, fertilization, transport, supervision in the fields, equipment maintenance and mechanized harvesting ${ }^{40}$. Along these lines, the data found in this study may 
be extended to sectors other than those crops analysed here, which, although they may not involve direct contact with plants, are indirectly involved with agricultural work, and are therefore potentially exposed to the same fungi.

Accordingly, other studies could be conducted in order to map more reliably the risks of rural work in respect of contamination of the oropharynx by filamentous fungi.

Although the contaminated workers did not present with any clinical manifestation as a consequence of this infection, it is important to stress that a proper evaluation of these workers should also entail examination of the oral mucosa in an attempt to rapidly control these infectious conditions.

\section{BIBLIOGRAPHY}

1.Clemente JC, Ursell LK, Parfrey LW, Knight R. The impact of the gut microbiota on human health: an integrative view. Cell. 2012;148(6):1258-1270.

2.Underhill DM, Iliev ID. The mycobiota: interactions between commensal fungi and the host immune system. Nature Publishing Group. 2014;14(6):405-416. doi:10.1038/nri3684.

3.Cui L, Morris A, Ghedin E. The human mycobiome in health and disease. Genome medicine. 2013;5(7):63. Available from: https://genomemedicine.biomedcentral.com/articles/10.1186/.

4.Ghannoum MA, Mukherjee PK. The Human Mycobiome and its Impact on Health and Disease. Current Fungal Infection Reports. 2013;7(4):345-350. Available from: http://link.springer.com/article/10.1007/s12281-013-0162-x.

5.Alexander P, Feine J, Huynh-Ba G, Vargas A, \& Oates TW. A critical review of diabetes, glycemic control and dental implant therapy. Clinical Oral Implants Research. 2013;24(2):117-127.

6.Vello LS. Saúde do trabalhador na atenção primária à saúde: estudo de caso em um município na região metropolitana de São Paulo [tese]. São Paulo: Universidade de São Paulo; 2015.

7.Brauner MCC, Zaro L. Saúde e meio ambiente: fatores condicionantes para a concretização do direito à saúde. JURIS, Rio Grande; 2012;17:53-74.

8.Arango M, Castañeda E. Micosis Humanas. Procedimientos diagnósticos. Exámenes directos. Ediciones Rojo, Medellín. Editorial Presencia, Santafé de Bogotá, 1995.

9.Pinheiro ET, Gomes P, Ferraz CC, Teixeira FB, Sousa-Filho SJ. Microorganisms from canals of rootfilled teeth with periapical lesions. International Endodontic Journal. 2003;36(1):1-11

10.Ortiz E, Ng RTY, Alliegro FC, Teixeira C, Muranaka EB, \& Sakano E. Microbiology of rhinosinusitis in immunosuppressed patients from the University Hospital. Brazilian journal of otorhinolaryngology. 2011;77(4):522-525. 
11.Lacaz CDS, Porto E, \& Martins JEC. Micologia médica: fungos, actinomicetos e algas de interesse médico. Revista do Instituto de Medicina Tropical de São Paulo. 1991;33(4):332-332

12.Stuart RM. Comunidade de fungos endofíticos associada à cana-de-açúcar convencional $e$ geneticamente modificada [tese]. Piracicaba: Escola Superior de Agricultura Luiz de Queiroz, Universidade de São Paulo; 2006

13. Steele DB, Stowers MK. Techniques for selection of industrially important microorganisms. Annual Review of Microbiology. 1991, v. 45, p. 89-106.

14.Giolo SR. Introdução à análise de dados categóricos: minicurso de estatística. Piracicaba: [s.n.], 2012. Disponível em: http://www.ufpr.br/ Giolo/CE073/. Acesso em: 10 fev. 2013

15.Gonzaga MA, Donatelli S, Tencarte APR, Adissi PJ, Santos EID. Análise coletiva do trabalho executado no cultivo do abacaxi no município de Guaraçaí, São Paulo. Ed. 2014. Disponível em: http://www.fundacentro.gov.br/.

16.Brasil. Agência de Informação: cana-de-açúcar. Disponível em: http://www.agencia.cnptia.embrapa.br/gestor/cana-deacucar/arvore/CONTAG01_110_22122006154841.html. Acessado em: maio 2010.

17.Brasil. Ministério Agricultura e Desenvolvimento, Cultura de frutas. Disponível em: https://www.agencia.cnptia.embrapa.br/gestor/cana-deacucar/arvore/CONTAG01_79_22122006154841.html. Acessado em: 03 set. 2011

18.Pranav PK, Patel T. Impact of ergonomic intervention in manual orange harvester among the workers of a hilly region in India. Work, n. Preprint, 2016, p. 1-9.

19.Brás S, Sabino R, Laureano A, Simões H, Fernandes C, Marques-Pinto G, Veríssimo C. Cutaneous infection by different Alternaria species in a liver transplant recipient. Medical Mycology Case Reports. 2015;8:1-4. Available from: http://doi.org/10.1016/j.mmcr.2015.01.004.

20.Martins-Dinis JN, da Silva RA, Miranda ET. Monitoramento de fungos anemofilos e de leveduras em unidades hospitalares. Revista de Saúde Pública. 2005;39(3):398-405

21.Ghannoum MA, Jurevic RJ, Mukherjee PK, Cui F, Sikaroodi M, Naqvi A, \& Gillevet PM. Characterization of the oral fungal microbiome (mycobiome) in healthy individuals. PLoS Pathogens. 2010;6(1). Available from: http://journals.plos.org/plospathogens/article?id=10.1371/journal.ppat.1000713

22.Pinto VdeS, Galesi VMN, Fukasava S, Vicentini AP. Vigilância Epidemiológica da Paracoccidioidomicose no Estado de São Paulo, 2008 a 2011. BEPA, Bol. epidemiol. paul. [online] 2012, v. 9, n. 103, p. 04-15 [citado 30 set. 2015]. Disponible en: http://periodicos.ses.sp.bvs.br/scielo.php?script=sci_arttext\&pid=S1806$42722012000700001 \& \operatorname{lng}=$ es\&nrm=iso.

23.Prasad SC, Kotigadde S, Shekhar M, Thada ND, Prabhu P, D’Souza T, \& Prasad KC. Primary otomycosis in the Indian subcontinent: predisposing factors, microbiology, and classification. International journal of microbiology. 2014. 
24.Magalhões EM. de S. Análise da prevalência de infecção pelo Paracoccidioides brasiliensis em áreas rurais de Alfenas, Minas Gerais [dissertação]. Alfenas: Universidade Federal de Alfenas; 2013.

25.dos Santos, DW; Wagner, R. Caracterização química parcial de polissacarídeos da parede celular de fusarium subglutinans. Saúde, v. 1, n. 3, 2014.

26. Vieira LA, Belfort Júnior RB, Fischman OF, Scarpi M. Estudo da flora fúngica da conjuntiva normal, da cana-de-açúcar e de anemófilos da região canavieira de Santa Rita, Paraíba, Brasil. Arq. bras. Oftalmol. 1989;52(3):63-7

27.Peleg AY, Hogan DA \& Mylonakis E. Medically important bacterial-fungal interactions. Nature Rev. Microbiol. 2010;8:340-349.

28.Graça MG. Avaliação de método molecular para detecção direta de Fusarium em água [tese]. São Paulo: Universidade de São Paulo; 2015

29.Querales PJ. Caracterização morfológica e genética de Fusarium spp. isolado de sementes $e$ associados a podridão do colmo do milho (Zea mays L.) [tese]. São Paulo: Escola Superior de Agricultura Luiz de Queiroz, Universidade de São Paulo; 2010.

30. Zukiewicz-Sobczak WA, Chmielewska-Badora J, Wróblewska P, Zwoliński J. Farmers' occupational diseases of allergenic and zoonotic origin. Postep Derm Alergol. 2013;30(5):311-315

31. Goes T, Bailão EFL, Correa CR, Bozzi A, Santos LI, Gomes A, \& Goes AM. New developments of RNAi in Paracoccidioides brasiliensis: prospects for high-throughput, genome-wide, functional genomics. PLoS Negl Trop Dis. 2014;8(10):e3173.

32. Brás S, Sabino R, Laureano A, Simões H, Fernandes C, Marques-Pinto G, Veríssimo C. Cutaneous infection by different Alternaria species in a liver transplant recipient. Medical Mycology Case Reports. 2015;8:1-4. Available from: http://doi.org/10.1016/j.mmcr.2015.01.004

33. Mohanraj D, Padmanaban P, Viswanathan R. Biological control of sugarcane diseases. In: Gnanamanickan SS. (Ed.). Biological control of crop diseases. Chennai: CRC PRESS; 2002, p. 161-78

34. de Azevedo FA, Lanza NB, Sales CRG, Silva KI, Barros AL, de Negri JD. Poda na citricultura. Citrus Research \& Technology, Cordeirópolis. 2013, v.34, n.1, 2013. p.17-30

35. Santarosa, E., Koller, O. C., Casamali, B., \& Petry, H. B. (2013). Production and physico-chemical quality of fruits in 'Valencia' orange trees with different pruning intensities and frequencies. Revista Brasileira de Fruticultura, 35(3), 790-798.

36. Robbins N, Uppuluri P, Nett J, Rajendran R, Ramage G, Lopez-Ribot JL, Cowen LE. Hsp90 governs dispersion and drug resistance of fungal biofilms. PLoS Pathogens. 2011;7(9). Available from: http://journals.plos.org/plospathogens/article?id=10.1371/journal.ppat.1002257.

37 Orasch C, Marchetti O, Garbino J, Schrenzel J, Zimmerli S, Mühlethaler K, Bille J. Candida species distribution and antifungal susceptibility testing according to European Committee on Antimicrobial Susceptibility Testing and new vs. old Clinical and Laboratory Standards Institute clinical breakpoints: a 6 year prospective candidaemia survey. Clinical Microbiology and Infection. 2014;20(7):698- 705. Available from: http://doi.org/10.1111/1469-0691.12440. 
38. Barbosa VS, Gomes VP, Petillo CR, Canabarro A. Presence of Candida sp. in diseased and healthy sites in patients with Chronic Periodontitis. Rev. Assoc. Paul. Cir. Dent. 2014;68(2):160-164.

39. Arushdeep S, Umar F. Sugarcane bagasse: a potential medium for fungal cultures. Chinese Journal of Biology. v. 2014.

40. Prado ML. Setor sucroalcooleiro, automação e novos gerenciamentos: novos perfis do trabalho. Estudos de Sociologia. 2011, v. 16, n. 31 